\title{
Pola Dakwah Tuan Guru Hasanain Juaini dalam Melestarikan Lingkungan
}

\author{
Aulia Fathul Aziz ${ }^{*}$, Yaya $^{2}$, \& Bahrudin ${ }^{2}$ \\ ${ }^{1}$ Jurusan Komunikasi dan Penyiaran Islam, Fakultas Dakwah dan Komunikasi, UIN Sunan \\ Gunung Djati, Bandung \\ 2Jurusan Manajemen Dakwah, Fakultas Dakwah dan Komunikasi, UIN Sunan Gunung Djati, \\ Bandung \\ *Email : fatalombok@gmail.com
}

\begin{abstract}
ABSTRAK
Tulisan ini bertujuan untuk mengetahui pola dakwah Tuan Guru Haji Hasanain Juaini, MH. dalam rangka melestarikan lingkungan. Secara rinci tujuan penelitian ini untuk mengetahui bagaimana kepribadian beliau, bagaimana kapasitas diri dan tujuan aktivitas komunikasi beliau yang membentuk pola dakwah pelestarian lingkungan. Metode penelitian menggunakan metode deskriptif yang melibatkan sumber data langsung dari objek penelitian dan keluaraga atau kerabat terdekat objek. Analisis data dengan analisis kualitatif. Hasil penelitian menunjukkan bahwa pola dakwah pelestarian lingkungan Tuan Guru Haji Hasanain Juaini, MH. terbentuk berdasarkan kepribadian yang menyampaikan apa yang beliau yakini dan telah beliau lakukan, siap menerima saran dan kritikan serta melakukan langsung apa yang beliau anjurkan kepada mad'u. Kapasitas diri beliau mendukung dalam mengeluarkan hukum fiqih lingkungan. Tujuan dakwah beliau adalah untuk membuat semua orang melakukan pelestarian lingkungan terutama umat Islam.
\end{abstract}

Kata Kunci : Pola Dakwah; Tuan Guru; Pelestarian Lingkungan

ABSTRACT

This paper aims to know the pattern of dawah of Tuan Guru Haji Hasanain Juaini in environment conservation. In detail this research aims to know how the personality of Tuan Guru Haji Hasanain Juaini, how the self capacity of him and the purpose of his communication activity forming the pattern of dawah of environment conservation. The research method used descriptive method involving data source from the research object directly and the object's family or relatives. Data analysis using qualitative analysis. The results showed Tuan Guru Haji Hasanain Juaini's pattern of dawah in environment conservation formed by the personality delivering what he believe and did, accepting suggestion and critics and doing what 
A. F. Aziz, Yaya, \& Bahrudin

be recommends to madu. The self capacity of him supports in issuing the fiqh's law of environment. His dawah purposed to make everyone doing the environment conservation especially people of Islam.

Keywords : Pattern of Da'wah; Tuan Guru; Environment Conservation

\section{PENDAHULUAN}

Istilah Tuan Guru di Lombok Nusa Tenggara Barat indentik dengan istilah "kiai" atau "haji" yang berkembang di Indonesia. Definisi kyai menurut Zamakhsyari Dhofier sebagaimana dikutip Tahir (2008: 94) dibedakan menjadi tiga yaitu: pertama, benda atau hewan yang dikeramatkan, seperti Kyai Plered (tombak), Kyai Naga Wilaga (gamelan perayaan sekaten di Yogyakarta, Kyai Rebo dan Kyai Wage (gajah di kebun binatang Gembira Loka Yogyakarta); kedua, orang tua pada umumnya; dan ketiga, orang yang memiliki keahlian dalam agama Islam, yang mengajar santri di pondok pesantren.

Tuan Guru adalah panutan bagi masyarakat sasak Lombok karena menjadi juru dakwah yang memiliki komitmen besar terhadap nilai-nilai kebenaran. Menurut Effendi (2013), sosok Tuan Guru dalam masyarakat sasak adalah figur yang sangat sentral di pesantren. Seiring semakin bertambahnya orang-orang berilmu di Lombok maka terjadi perubahan nilai dan makna Tuan Guru menjadi cendekiawan.

Mengingat dewasa ini permasalahan dan tantangan umat Islam semakin kompleks, para da'i tertuntut untuk mengembangkan metode dakwahnya yang dapat menjawab problematika kehidupan umat Islam. Diantara metode-metode yang berkembang di tengah para da'i adalah dengan perbuatan atau dakwah bi alhal. Perbuatan yang meliputi keteladanan dan tindakan amal karya nyata yang hasilnya dapat dirasakan secara konkret oleh masyarakat selaku objek dakwah (Amin, 2009: 11).

Mantan Gubernur Nusa Tenggara Barat Dr. Tuan Guru Haji Muhammad Zainul Majdi, MH. merupakan contoh Tuan Guru yang berdakwah dengan perbuatan dalam dunia politik, disamping beliau menjadi ketua umum pengurus besar ormas Islam Nahdlatul Wathan yang ada di Lombok. Ada pula Tuan Guru yang berdakwah dengan kerja nyata pelestarian lingkungan dan penghijauan di wilayah Nusa Tenggara Barat, dialah Tuan Guru Haji Hasanain Juaini, MH., Pimpinan Pondok Pesantren Nurul Haramain NW Narmada Lombok Barat.

Kerusakan lingkungan di kawasan Lombok menjadi perhatian Tuan Guru Haji Hasanain Juaini, MH. selama 20 tahun terakhir. Tidak jarang kerusakan itu menyebabkan kekeringan di beberapa tempat dan berbagai bencana alam disebabkan kondisinya yang tidak terawat. Kerusakan lingkungan yang mengakibatkan global warming atau pemanasan global tidak lain karena ulah manusia. Dampak yang diakibatkan sangat meluas dan sering merugikan sehingga menjadi perhatian dunia internasional. Kerusakan yang terjadi di bumi 
ini sebenarnya telah Allah firmankan dalam QS. Ar-Rum: 41 yang artinya

"Telah nampak kerusakan di darat dan di laut disebabkan karena perbuatan tangan manusia, supaya Allah merasakan kepada mereka sebahagian dari (akibat) perbuatan mereka, agar mereka kembali (ke jalan yang benar)" (Depag RI, 2015: 408).

Mengajak dan mengajarkan memperbaiki lingkungan tentu sesuai dengan konsep dakwah yaitu mengajak kepada kebaikan dan mencegah dari kemungkaran, sebagaimana firman Allas Swt. dalam QS. Ali Imron: 104 yang artinya: "Dan hendaklah ada di antara kamu segolongan umat yang menyeru kepada kebajikan, menyuruh kepada yang ma' ruf dan mencegah dari yang munkar; merekalah orang-orang yang beruntung" (Depag RI, 2015: 63). Masyarakat diajak untuk kembali melestarikan lingkungan sekitar mereka dan diajarkan untuk tidak hanya mengambil manfaat dari lingkunganya sehingga terjadi kerusakan. Merubah pola fikir dan gaya hidup mad'u tentulah memerlukan metode yang baik dan tepat, apalagi memberi pamahaman kepada masyarakat yang menggantungkan hidupnya kepada hasil bumi dari hutan.

Sebagaimana yang dilakukan Tuan Guru Haji Hasanain Juaini, MH. yang telah berhasil menggerakkan santri dan masyarakat di Nusa Tenggara Barat untuk melestarikan lingkungan dengan cara menanam pohon. Beliau berhasil menghijaukan kembali 56 hektar lahan gundul yang ada di Lombok. Mengutip wawancara Hananto dari Mongabay (2014) pada tahun 2003 silam beliau membeli lahan gundul dan gersang seluas 36 hektar, dan sekarang telah menjadi kawasan konservasi hutan yang diberi nama Desa Madani. Pada tahun 2016 beliau menerima penghargaan Kalpataru katagori Pembina Lingkungan dari Kementrian Lingkungan Hidup dan Kehutanan yang diberikan langsung oleh Wakil Presiden RI Bapak Dr. (HC) H. Muhammad Jusuf Kalla di Istana Siak Sri Inderapura Kabupaten Siak, Riau.

Sebagai pembanding dan untuk membedakan dengan penelitian sebelumnya, berikut adalah beberapa penelitian yang relevan diantaranya adalah; penelitian yang dilakukan oleh Mantilina Ervina (2015: 84) tentang Pola Komunikasi Tuan Guru Dalam Melestarikan Lingkungan Hidup. Penelitian ini membahas tentang pola komunikasi dan kiprah Tuan Guru Haji Hasanain Juaini, MH. dalam rangka melestarikan lingkungan. Penelitian ini menemukan bahwa pola komunikasi yang diterapkan dalam melestarikan lingkungan hidup adalah komunikasi informatif (informative communication) dan komunikasi persuasif (persuasive communication).

Penelitian yang dilakukan oleh Arif Nurjaman (2016: 305) tentang Pola Komunikasi Kyai dalam Memelihara Solidaritas Jamaah. Penelitian ini didasarkan pada teori komunikasi, identitas dan teori solidaritas. Penelitian dengan metode studi kasus ini menemukan bahwa pola komunikasi kyai dalam memelihara 


\section{A. F. Aziz, Yaya, \& Bahrudin}

solidaritas Jamaah adalah: (1) Pola komunikasi aksi, (2) Pola komunikasi interaksi, dan (3) Pola komunikasi transaksi.

Penelitian yang dilakukan oleh Yoga Hadi Permana (2016: 37) tentang Pola Tabligh Organisasi Jamiyah Nurul Iman Bandung. Penelitian yang bersifat kualitatif ini menemukan bahwa komunikasi dalam kegiatan tabligh lebih banyak mengajak serta mempengaruhi jama'ah untuk merealisasikan pesan-pesan keislaman yang disampaikan mubaligh melalui tindakan-tindakan yang dilakukan mubaligh serta didukung oleh kegiatan-kegiatan tabligh dalam organisasi Jamiyah Nurul Iman.

Berdasarkan penelusuran penulis terhadap kajian terdahulu, ada beberapa hasil penelitian yang membahas tentang pola komunikasi, sebagaimana dijelaskan di atas. Akan tetapi, belum ada penelitian yang khusus membahas tentang pembentuk pola dakwah yang dilakukan seorang Tuan Guru dalam rangka melestarikan lingkungan. Untuk itu penelitian tentang pola dakwah Tuan Guru Haji Hasanain Juaini, MH. dalam rangka melestarikan lingkungan merupakan penelitian baru dan menarik dalam rangka menambah informasi berkaitan dengan dakwah di lembaga keagamaan.

Lokasi penelitian kali ini yaitu: pertama, di Pondok Pesantren Nurul Haramain NW Kecamatan Narmada Kabupaten Lombok Barat; kedua, di lokasi konservasi hutan Desa Madani di Dusun Lebah Suren Desa Sedau Kecamatan Narmada Kabupaten Lombok Barat.

Dari latar belakang penelitian yang telah dijelaskan di atas, dirumuskan beberapa fokus penelitian yaitu: bagaimana kepribadian Tuan Guru Haji Hasanain Juaini, MH. yang membentuk pola dakwah pelestarian lingkungan? bagaimana kapasitas diri Tuan Guru Haji Hasanain Juaini, MH. yang membentuk pola dakwah pelestarian lingkungan? bagaimana maksud dan tujuan aktivitas komunikasi Tuan Guru Haji Hasanain Juaini, MH. yang membentuk pola dakwah pelestarian lingkungan?

Penelitian ini menggunakan metode deskriptif. Dengan menganalisis data yang terkumpul dari hasil observasi dan wawancara dengan Tuan Guru Haji Hasanain Juaini, MH., keluarga dan kerabat beliau.

\section{LANDASAN TEORITIS}

Teori yang dijadikan landasan dalam penelitian ini adalah teori dakwah Islam, dan teori pola komunikasi dakwah. Kata dakwah secara etimologi, berasal dari kata bahasa Arab da'a-yad'u-da'watan, yang artinya mengajak, menyeru atau memanggil. Warson Munawwir menyebutkan sebagaimana dikutip oleh Amin (2009: 1) bahwa arti dari dakwah adalah memanggil (to call), mengundang (to invite), mengajak (to summon), menyeru (to propose), mendorong (to urge) dan memohon (to pray).

Menurut Muhammad Fuad Abdul Baqi sebagaimana dikutip oleh Amin 
(2009: 2) kata dakwah dan kata-kata yang terbentuk darinya tidak kurang dari 213 kali disebutkan di dalam Alquran. Dengan demikian, secara etimologi dakwah dan tabligh adalah suatu proses penyampaian (tabligh) atas pesan-pesan tertentu yang berupa ajakan atau seruan dengan tujuan agar orang lain memenuhi ajakan tersebut.

Definisi dakwah secara terminologi telah banyak dibuat oleh para ahli yang dapat melengkapi satu sama lain. Hakikat dan makna yang dimaksud tetap sama meskipun berbeda susunan redaksinya. Diantara definisi dari para ahli tersebut ialah menurut Prof. Toha Yahya Omar, M.A. sebagaimana dikutip oleh Amin (2009: 3) dakwah ialah "mengajak manusia dengan cara bijaksana kepada jalan yang benar sesuai dengan perintah Tuhan, untuk keselamatan dan kebahagiaan mereka di dunia dan akhirat".

Menurut syaikh Ali Mahfudz sebagaiman dikutip oleh Amin (2009: 3) dakwah adalah "Memotifasi manusia untuk berbuat kebajikan, mengikuti petunjuk, memerintahkan kebaikan dan mencegah kemungkaran agar mereka memperoleh kebahagiaan di dunia dan akhirat."

Menurut M. Natsir sebagaiman dikutip oleh Amin (2009: 3),

"Dakwah adalah usaha-usaha menyerukan dan meyampaikan kepada perorangan manusia dan seluruh umat manusia konsepsi Islam tentang pandangan dan tujuan hidup manusia di dunia ini, dan yang meliputi alamar bi al-ma'ruf an-nahyu an al-munkar dengan berbagai macam cara dan media yang diperbolehkan akhlak dan membimbing pengalamannya dalam perikehidupan bermasyarakat dan perikehidupan bernegara."

Menurut Ibnu Taimiyah sebagaiman dikutip oleh Amin (2009: 3),

"Dakwah merupakan suatu proses usaha untuk mengajak agar orang beriman kepada Allah, percaya dan mentaati apa yang telah diberitakan oleh Rasul serta mengajak agar dalam menyembah kepada Allah seakanakan melihat-Nya".

Dengan demikian dakwah dapat pula diartikan sebagai sebuah proses penyampaian ajaran agama Islam kepada umat manusia. Sebagai suatu proses, dakwah tidak hanya merupakan usaha penyampaian saja, tetapi merupakan usaha untuk mengubah way of thinking, way of feeling, dan way of life manusia sebagai sasaran dakwah ke arah kualitas kehidupan yang lebih baik (Amin, 2009: 5).

Hukum berdakwah menurut Muhammad Abu Zahrah sebagaimana dikutip oleh Aziz (2009: 153) adalah fardlu 'ain dan kifayah. Menurutnya berdakwah fardlu 'ain dilakukan secara individual (al-ahad) dan fardlu kifayah melakukannya dalam dakwah kolektif (al-jama'at). Setiap individu muslim berkewajiban untuk melakukan dakwah individual. Kendati demikian, di kalangan umat Islam harus ada tenaga ahli yang berkaitan dengan dakwah Islam. Semua kewajiban ini harus ditopang oleh negara. Jadi, negara berkewajiban 


\section{A. F. Aziz, Yaya, \& Bahrudin}

mendirikan lembaga-lembaga dakwah Islam serta mengkader calon-calon pendakwah.

Terdapat tiga macam golongan pendakwah sebagaimana dijelaskan oleh Aziz (2009: 154) yaitu pendakwah mujtahid, pendakwah muttabi', dan pendakwah muqallid. Para ulama termasuk golongan pertama, mereka mampu membuat penafsiran ayat dan hadis secara benar, lalu menyampaikannya kepada masyarakat. Mereka terbebani dakwah fardhu 'ain. Hukum ini juga berlaku untuk golongan kedua, pendakwah muttabi'. Pendakwah muttabi’ adalah orang-orang yang mengajak orang lain dengan menampilkan dalil yang diketahuinya. Umumnya kelompok ini relatif paling banyak. Para pendakwah kita umumnya masih dalam taraf ini. Mereka membaca karya para ulama, lalu menyampaikannya kepada masyarakat. Sedangkan untuk kelompok ketiga pendakwah muqallid terkena kewajiban fardhu kifayah, karena kelompok yang terakhir ini memiliki pengetahuan yang amat terbatas.

Tujuan dilakukannya dakwah adalah agar tercipta suatu tatanan kehidupan individu dan masyarakat yang aman, damai, dan sejahtera yang dinaungi oleh kebahagiaan, jasmani maupun rohani, dalam pancaran sinar agama Allah dengan mengharap ridha-Nya. Menurut Bambang Saeful Ma'arif (2010: 26) tujuan dakwah seyogianya dicermati dengan baik agar dapat membuahkan keluaran yang terukur. Dalam kehidupan yang terus menerus mengabadikan berbagai kebijakan dakwah Nabi, aktivitas dakwah dilakukan dengan senantiasa mengharapkan ridha Allah Swt.

Di dalam aktivitas dakwah perlu diperhatikan unsur-unsur atau komponen-komponen yang terkandung dalam setiap kegiatan dakwah. Ilahi (2010: 19-22) menjelaskan Unsur-unsur tersebut di antaranya: (1) Da'i, (2) Mad'u, (3) Materi/Pesan dakwah, (4) Media dakwah, (5) Metode dakwah.

Pola dakwah meliputi dua kata yaitu pola dan dakwah, dalam kamus ilmiah popular dijelaskan pola berarti sistem atau cara kerja. Dari perspektif ilmu komunikasi menurut Siahaan sebagaimana dikutip oleh Ma'arif (2010: 78) pola menyangkut pesan yang terkait dengan situasi dan kondisi yang mengacu pada sesuatu yang membungkus inti pesan itu sendiri.

Pola memberikan data untuk memahami dan mengerti tindakan atau tingkah laku seseorang, kelompok (jama'ah) atau organisasi yang muncul. Pola komunikasi menunjukkan suatu identifikasi untuk mengakses tingkah laku komunikasi dalam suatu sistem karena pola komunikasi menyediakan konteks atau ruang untuk memahami tingkah laku yang spesifik (Ma'arif, 2010: 78).

Pola komunikasi menurut Katz dan Kahn sebagaimana dikutip oleh Ma'arif (2010: 78) disesuaikan dengan kondisi anggota dan komunikan yang ada saat berinteraksi dengan lingkungannya. Pola ini menurut mereka bila dihubungkan dengan figur komunikator, pesan, dan media (tertulis, audio, dan video) akan menjadi suatu rangkaian yang beragam dan berkembang dalam suatu 
rangkaian di mana retorika mengarahkan tujuan pembinaan komunikasi dakwahnya.

Dalam pembentukan pola komunikasi Ma'arif (2010: 79) menjelaskan terdapat 3 faktor yang mempengaruhi yaitu: (1) proses sejarah atau pengalaman masa lalu yang kemudian membentuk kebiasaan-kebiasaan yang menjadi bagian dari kepribadian, (2) kapasitas diri sebagai akibat dari faktor pendidikan, pelatihan serta pengalaman hidup diri seseorang dalam menempuh kehidupan, dan (3) maksud dan tujuan dari aktivitas komunikasi sehingga membawa kepada penyesuaian pesan, metode, dan media yang dipergunakan.

Masing-masing komunikator dakwah memiliki kekuatan yang perlu dicermati secara bijak. Menurut Ma'arif (2010: 79) masing-masing pribadi memiliki potensi unggulan yang dapat dimanfaatkan untuk kepentingan komunikasi dakwah, misalnya melalui analisis diri (self analysis atau tabshirah). Seseorang berupaya mengembangkan potensi diri agar kekuatan diri dapat teraktualisasi. Masing-masing memiliki bakat dan karakter yang dapat digali sebanyak mungkin yang berpengaruh melampaui batas-batas dirinya.

\section{HASIL DAN PEMBAHASAN}

Tuan Guru Haji Hasanain Juaini, MH. adalah Pimpinan Pesantren Nurul Haramain NW di Narmada Lombok Barat. Beliau juga merupakan Ketua Yayasan Perguruan Pondok Pesantren Nahdhatul Wathan (YPPPNW) Narmada, yang menaungi Pesantran Nurul Haramain NW dan beberapa lembaga pendidikan dasar dan menengah yang ada di Kecamatan Narmada. Yayasan dan pesantren tersebut adalah peninggalan orang tua beliau. Di waktu remaja beliau sudah ikut mengajar di yayasan tersebut untuk membantu orang tua beliau.

Sejak awal mendirikan pesantren, Tuan Guru Haji Hasanain Juaini, MH. sudah sangat mengenal teknologi komputer dan internet. Pada tahun 1996 belum lama setelah beliau kembali dari belajar di perguruan tinggi LIPIA Jakarta, beliau mendirikan Pesantren Nurul Haramain NW Putri. Pesantren tersebut berlokasi di alamat rumah Tuan Guru Haji Hasanain Juaini, MH. saat ini. Di awal perjalanan pembangunan dan pengembangan pesantren putri tersebut, Tuan Guru mengandalkan teknologi dari komputer dan internet yang beliau beli dengan harga 15 juta rupiah. Dengan teknologi internet tersebut, beliau bersama Ust. Syamsi Ali menjadi tutor dalam sebuah portal dakwah islam.net yang mempertemukan beliau dengan orang-orang dari dalam dan luar negeri. Dari sana pula beliau membangun relasi yang dapat membantu dan mendukung pembangunan dan pengembangan pesantren putri tersebut.

Semenjak berdirinya Pesantren Nurul Haramain Putri ini juga, Tuan Guru Haji Hasanain Juaini, MH. mulai mendalami isu pluralisme dan gender, yang 


\section{A. F. Aziz, Yaya, \& Bahrudin}

berpengaruh pada program-program yang diterapkan di dalam lingkungan pesantren putri tersebut. Gagasan-gagasan mengenai pemberdayaan perempuan yang beliau realisasikan di dalam pesantren ini membuat beliau dikenal oleh khalayak masyarakat dan mengundang perhatian pihak-pihak pemerintah meupun swasta. Disamping itu juga menarik perhatian LSM yang ada pada tingkat lokal maupun nasional bahkan internasional, sehingga pada tahun 2003 silam, beliau dianugrahkan lencana Ashoka Internastional dari Amerika Serikat.

Hasil penelitian ini menemukan kepribadian Tuan Guru Haji Hasanain Juaini, MH., kapasitas diri beliau serta maksud dan tujuan aktivitas komunikasi beliau yang membentuk pola dakwah pelestarian lingkungan.

\section{Kepribadian Tuan Guru Haji Hasanain Juaini, MH.}

Berdakwah sebagaimana tercantum dalam QS. An-Nahl: 125 ialah "dengan hikmah dan pelajaran yang baik dan bantahlah mereka dengan cara yang baik" (Depag RI, 2015: 281). Tuan Guru Haji Hasanain Juaini, MH meyakini bahwa maksud berdakwah denga cara hikmah ialah mengajak orang untuk menunaikan perintah Allah dan memahami apa yang dikehendaki oleh-Nya dengan cara dan bahasa yang bisa dipahami oleh mad'u (Wawancara dengan Tuan Guru Haji Hasanain Juaini, 20 Juni 2018).

Disamping dengan cara hikmah Tuan Guru Haji Hasanain Juaini, MH juga menambahkan bahwa da'i juga harus memiliki modal yang cukup dan juga pengetahuan mengenai latar belakang mad'unya sehigga mendekatkan mad'u pada pemahaman yang benar. Sebagaimana yang beliau ungkapkan "kita harus punya modal yang cukup agar orang yang kita ajak berbicara itu, objek dakwah kita itu memahami apa yang dikehendaki oleh Allah" (Wawancara dengan Tuan Guru Haji Hasanain Juaini, 20 Juni 2018).

Selain dengan cara hikmah sebagaimana disebutkan dalam QS. An-Nahl: 125, dilanjutkan dengan cara memberikan "pelajaran yang baik" (Depag RI, 2015: 281). Menurut Tuan Guru Haji Hasanain Juaini, MH. cara memberikan pelajaran yang baik adalah dengan memberi contoh dalam melakukan hal yang didakwahkan oleh seorang da'i. da'i harus sudah melakukan apa yang dia dakwahkan kepada mad'unya, dengan begitu da'i menjadi semakin yakin dengan apa yang dia sampaikan dan mad'unya juga ikut meyakini apa yang didakwahkan oleh da'i itu adalah sesuatu yang benar (Wawancara dengan Tuan Guru Haji Hasanain Juaini, 20 Juni 2018).

Tuan Guru Haji Hasanain Juaini, MH. sering melakukan diskusi atau bertukar pikiran dengan tamu atau kerabat LSM yang mengunjungi beliau. Sehingga suatu ketika salah seorang dari LSM, mengkritik beliau yang dianggap kurang peduli terhadap lingkungan. Hal tersebut terjadi setelah berdirinya pesantren putri yang beliau asuh. Berikut kutipan cerita yang penulis kutip dari wawancara beliau dengan Majalah Suara Hidayatullah (2012: 86), 
Suatu kali saya mendapat kritik yang sangat pedas. Mereka bilang, "katanya Islam mengajarkan kehidupan itu ibarat air. Dan ajaran Islam juga sangat tergantung pada air. Sekarang air kita bermasalah, kalian (pesantren) kok tidak ada yang bergerak. Kalian masih asyik berdiri di menara gading. Yang bergerak malah orang-orang non-muslim", dari situlah saya tersentak.

Apa yang mereka bilang benar. Dan saya pikir memang harus ada di antara kita (umat Islam) yang bergerak. Karena saya tahu pesantren-pesantren lain lebih sibuk ke dalam, biarlah saya mewakili mereka membayar utang kepada alam. Alam telah memberi demikian banyak kepada manusia, tetapi manusia belum membalasnya. Jadi terjunnya saya di lingkungan semacam panggilan Ilahi.

Istilah tuan guru yang identik dengan isltilah kyai sebagaimana didefinisikan Zamakhsyari Dhofier yang dikutip oleh Tahir (2008: 94) adalah orang yang memiliki keahlian dalam agama Islam, yang mengajar santri di pondok pesantren. Tuan Guru Haji Hasanain Juaini, MH. juga ingin mengajak masyarakat disekitar untuk melakukan pelestarian lingkungan ini, dikarenakan pekerjaan memperbaiki lingkungan tersebut bukanlah pekerjaan kecil dan bisa dilakukan seorang diri. Oleh karena itu dalam setiap ceramah beliau menambahkan materi tentang urgennya melakukan pelestarian lingkungan. Dalil Alquran dan Hadis yang diyakini adalah perintah agama untuk menjaga dan melestarikan lingkungan juga beliau sampaikan sebagai landasan untuk melakukannya.

Disamping karena dorongan perintah agama untuk menjaga lingkungan, Tuan Guru Haji Hasanain Juaini, MH. juga mengungkapkan bahwa alasan rasional manusia harus menjaga alam karena alam menjadi sumber penghidupan mereka. Sebagaimana beliau menuturkan "secara rasional kan kita harus menjaga alam kita sendiri, yang menjadi sumber penghidupan kita. Ya kalau secara rasional, ya kalau kita tidak jaga sumber kehidupan kita sama saja dengan kita bunuh diri kan itu, dan karena ini merupakan pekerjaan besar yang wajib dilakukan oleh semua manusisa" (Wawancara dengan Tuan Guru Haji Hasanain Juaini, 20 Juni 2018).

Usaha untuk mengajak masyarakat sasak Lombok untuk melakukan pelestarian lingkungan tidak cukup hanya melalui pendekatan ceramah. Menurut Tuan Guru Haji Hasanain Juaini, MH. hal itu disebabkan watak kritis masyarakat sasak yang tidak cepat mengklaim sebuah kebenaran jika bersumber dari sebuah opini. Watak kritis itu tergambar pada sebuah pantun Bahasa Sasak 'Pelisak bawon batu, lamung'k ndek gitak ndek'h sadu'. Artinya orang sasak sendiri akan mengklaim sesuatu itu benar atau salah jika sudah dilihat dan didengar dengan mata dan telinga mereka sendiri. 
Sebagaimana pemahaman Tuan Guru Haji Hasanain Juaini, MH. tentang perintah QS. An-Nahl: 125 "serulah kepada jalan tuhanmu dengan hikmah dan pelajaran yang baik dan bantahlah mereka dengan cara yang baik" (Depag RI, 2015: 281). Memberikan pelajaran yang baik beliau lakukan dengan berinisiatif mengajak semua penghuni pesantren untuk terjun langsung melakukan perbaikan dan pelestarian lingkungan dari dalam pesantren terlebih dahulu. Baliau ingin menunjukkan langsung kepada masyarakat bahwa memperhatikan kelestarian alam yang ada di sekitar mereka adalah hal yang sangat penting, dan beliau bersama santri dan santriwatinya bisa melakukannya.

Bekerja keras telah menjadi hobi Tuan Guru Haji Hasanain Juaini, MH. yang menjadikan beliau dianggap 'gila kerja' oleh istri beliau $\mathrm{Hj}$. Runiati. Mengutip wawancara istri beliau dengan Majalah Suara Hidayatullah (2012: 87) bahwa Tuan Guru dianggap 'gila kerja' karena sering kali beliau tak bisa tidur jika pekerjaan belum selesai. Beliau benar-benar bekerja habis-habisan untuk kembali melestarikan lingkungan yang rusak di sekitar beliau. Di awal memulai pekerjaan ini sering kali beliau pulang pada jam tiga dini hari dari hutan. Hal demikian beliau lakukan karena penghijauan lahan yang rusak di daerah Lombok harus segera dilaksanakan karena bila terlambat maka proses penggurunan tidak dapat terelakkan (Wawancara dengan Tuan Guru Haji Hasanain Juaini, 20 Juni 2018).

Sebagai bentuk memberikan contoh kepedulian kepada lingkungan, Tuan Guru Haji Hasanain Juaini, MH. juga banyak menanam bermacam-macam tumbuhan bunga yang menghiasi halaman rumah beliau. Bibit-bibit bunga tersebut beliau kumpulkan dari tempat mana saja yang dikunjungi dalam kegiatan dakwah beliau. Ini berdasarkan pengamatan dan hasil observasi penulis dan sebagaimana diungkapkan istri beliau "menanam sudah seperti bagian dari hidupnya karena setiap hari dia selalu meluangkan waktu kosongnya untuk menanam" (Wawancara dengan Hj. Runiati, 18 Juni 2018).

Proses sejarah yang menuntun Tuan Guru Haji Hasanain Juaini, MH. dan memeberikan beliau pengalaman untuk melakukan pelestarian lingkungan serta mendakwahkannya kepada masyarakat telah mempengaruhi kebiasaan-kebiasaan dalam hidup beliau yang juga menjadi kepribadian beliau. Hal tersebut sesuai dengan faktor pembentuk pola komunikasi sebagaimana diungkapkan oleh Bambang Saiful Ma'arif (2010: 79) bahwa faktor yang mempengaruhi pembentukan pola komunikasi seseorang yaitu proses sejarah atau pengalaman masa lalu yang kemudian membentuk kebiasaan-kebiasaan yang menjadi bagian dari kepribadian.

\section{Kapasitas diri Tuan Guru Haji Hasanain Juaini, MH.}

Salah satu pribahasa yaitu 'buah jatuh tak jauh dari pohonnya' sekiranya dapat menggambarkan keadaan Tuan Guru Haji Hasanain Juaini, MH. Ayah beliau 
juga seorang tuan guru, dialah Tuan Guru Haji Muhammad Djuaini Muchtar, salah seorang murid Tuan Guru Kyai Haji Muhammad Zainuddin Abdul Madjid yang sekarang telah dinobatkan sebagai Pahlawan Nasional dari Lombok Nusa Tenggara Barat.

Tuan Guru Haji Hasanain Juaini, MH. menjadikan ayah beliau sebagai teladan dalam berdakwah dan menjadi tuan guru. Beliau banyak meniru sikap dan tingkah laku ayah beliau dalam menjalani hidup dan juga berdakwah kepada masyarakat. Menjadi keluarga guru sebagaimana disampaikan ayah beliau seperti telah terpatri dalam jiwa beliau, bukan hanya untuk beliau sendiri, melainkan juga berlaku kepada saudara-saudara beliau yang lain (Wawancara dengan $\mathrm{Hj}$. Runiati, 18 Juni 2018).

Untuk mewujudkan guru itu sebagaimana perintah Allah Swt dalam QS. At-Taubah: 122 "Mengapa tidak pergi dari tiap-tiap golongan di antara mereka beberapa orang untuk memperdalam pengetahuan mereka tentang agama dan untuk memberi peringatan kepada kaumnya apabila mereka telah kembali kepadanya" (Depag RI, 2015: 206), maka Tuan Guru Haji Hasanain Juaini, MH. sejak masa pendidikan dasar bersekolah di lembaga keagamaan seperti Madrasah Ibtidaiyah Tanak Beak yang lulus pada tahun 1975. Kemudian melanjutkan di Madrasah Tsanawiyah Narmada dan lulus pada tahun 1979. Lalu melanjutkan pendidikan tingkat SMU di KMI Pondok Modern Gontor dan lulus pada tahun 1984 (Wawancara dengan Tuan Guru Haji Hasanain Juaini, 20 Juni 2018).

Pada masa setelah kelulusan Tuan Guru Haji Hasanain Juaini, MH. dari Madrasah Tsanawiyah Narmada, beliau memiliki keinginan untuk mampu membaca kitab-kitab berbahasa Arab yang dimiliki ayah beliau. Beliau ingin belajar di tempat yang bisa mengajarkan beliau bahasa Arab dan membaca kitabkitab Arab. Karena itulah beliau melanjutkan ke Pondok Modern Gontor pada tahun 1980. Beliau mengikuti saran salah seorang paman beliau yang pernah mengenyam pendidikan di pesantren tersebut, karena Gontor juga merupakan pesantren yang mendidik santrinya untuk menjadi guru (Wawancara dengan Tuan Guru Haji Hasanain Juaini, 20 Juni 2018).

Selama nyantri di Pondok Modern Gontor, Tuan Guru Haji Hasanain Juaini, MH. belajar dan mendapat prestasi yang gemilang. Tidak hanya belajar bahasa Arab tapi juga bahasa Inggris yang kini beliau pandai menggunakan kedua bahasa tersebut. Karena kamampuan bahasa beliau yang baik maka ketika menjadi kelas akhir beliau diberi kepercayaan sebagai pengurus bagian penerangan yang juga berkutat pada kedua bidang bahasa tersebut (Wawancara dengan Tuan Guru Haji Hasanain Juaini, 20 Juni 2018).

Disamping memperolah berbagai ilmu pengetahuan dan ilmu agama di Pondok Modern Gontor, Tuan Guru Haji Hasanain Juaini, MH juga mendapat begitu banyak pengalaman dan pelajaran hidup dari apa yang beliau alami dan 


\section{A. F. Aziz, Yaya, \& Bahrudin}

rasakan di sana. Gontor talah banyak memberi pengaruh kepada diri beliau, terutama oleh tokoh pendiri Pondok Modern Gontor yang sangat beliau kagumi dan hormati KH. Imam Zarkasyi. Sikap-sikap dan pendidikan KH. Imam Zarkasyi telah menjadi teladan bagi beliau. Akhirnya setelah dinyatakan lulus dari Gontor beliau diberi kepercayaan untuk mengabdi sebagai guru di Gontor selama satu tahun hingga tahun 1985.

Tidak lama setelah kembali dari Gontor, Tuan Guru Haji Hasanain Juaini, MH. merantau ke Malaysia menjadi seorang guru agama. Pada masa itu di tahun 1985 beliau mengungkapkan bahwa apa yang beliau sebut The Revival of Islam yang membangun semangat persatuan antara Malaysia dan Indonesia sangat terasa bagi beliau dan mempengaruhi semangat beliau saat berada di negeri jiran tersebut (Wawancara dengan Tuan Guru Haji Hasanain Juaini, 20 Juni 2018).

Setelah setahun lebih berkeliling menjadi guru agama di Malaysia, beliau akhirnya mendapat tawaran menjadi pengajar di sebuah lembaga pendidikan di daerah Kelantan. Pada saat hendak memperpanjang visa tinggal di kantor imigrasi, beliau melihat begitu banyak TKI yang ditangkap karena melakukan kesalahan di sana. Melihat fenomena demikian beliau berpikir "lho kok saya gilagilaan ngajarin orang ke sini, mendingan saya pulang ngajarin bangsa saya" ungkap beliau dalam acara Kick Andy MetroTV edisi Maret 2012 sebagaimana dikutip oleh Darmawan (2013: 103).

Dengan bekal menguasai bahasa Arab dan Inggris yang diperoleh di Gontor, Tuan Guru Haji Hasanain Juaini, MH. melanjutkan pendidikan ke jenjang perguruan tinggi di LIPIA Jakarta pada 1991. Beliau mendalami ilmu fiqih, ushul fiqih dan segala bentuk ilmu hukum Islam dengan masuk di Jurusan Hukum Fakultas Syariah dan lulus pada tahun 1995 dengan gelar Lc. (License). Dengan pemahaman ilmu fiqih tersebut beliau yang kini telah mengeluarkan hukum fiqih lingkungan sebagai landasan hukum dalam melakukan perintah Allah Swt untuk melestarikan lingkungan. Karena itu beliau saat ini diberi gelar tuan guru kitab hijau (Wawancara dengan Tuan Guru Haji Hasanain Juaini, 20 Juni 2018).

Berdasarkan hasil wawancara dengan Tuan Guru Haji Hasanain Juaini, MH., disamping menjalani perkuliahan di LIPIA, beliau juga menjadi pengurus perwakilan ormas Nahdlatul Wathan di Jakarta. Tidak hanya sampai pada jenjang sarjana, Tuan Guru Haji Hasanain Juaini, MH. selanjutnya menempuh pendidikan pascasarjana di Universitas Mataran pada Prodi Ilmu Hukum pada tahun 2004. Beliau menyelesaikan program masgisternya pada tahun 2006 dengan memperoleh gelar MH. (Magister Hukum).

Dari hasil pengamatan dan observasi penulis, Tuan Guru Haji Hasanain Juaini, MH. adalah sosok yang suka membaca buku. Beliau memiliki koleksi buku yang bermacam-macam. Selain buku berbahasa Indonesia, ada yang berbahasa Inggris dan juga beberapa kitab bahasa Arab. Setelah membaca buku- 
buku itu, beliau tidak hanya menyimpannya ke dalam rak-rak yang sekarang sudah penuh. Dengan memanfaatkan teknologi scanner, beliau mendigitalkan buku-buku itu dan disalin ke dalam digital library pesantren agar dapat dibaca oleh siapa saja.

Dari hasil membaca buku pula Tuan Guru Haji Hasanain Juaini, MH. mendapatkan pengetahuan mengenai cara-cara melestarikan lingkungan. Beliau mengatakan bahwa ilmu melestarikan lingkungan ini beliau pelajari dengan otodidak disamping langsung terjun ke dalam hutan bersama warga yang tinggal di pinggiran hutan (Wawancara dengan Tuan Guru Haji Hasanain Juaini, 20 Juni 2018). Beliau kerap melakukan diskusi dengan para ahli di bidang lingkungan ketika diundang pada acara-acara seminar atau forum-forum ilmiah lainnya. Dari sana pula beliau bertukar pikiran dengan para ahli mengenai program pelestarian yang beliau jalankan. Beliau juga pernah diundang menjadi narasumber pada acara seminar internasional dengan tema lingkungan di Malaysia dan Thailand.

Kapasitas pendidikan dan pengalaman Tuan Guru Haji Hasanain Juaini, MH. untuk melakukan pelestarian lingkungan serta mendakwahkannya kepada masyarakat, sesuai dengan faktor pembentuk pola komunikasi sebagaimana diungkapkan oleh Bambang Saiful Ma'arif (2010: 79) bahwa kapasitas diri sebagai akibat dari faktor pendidikan, pelatihan serta pengalaman hidup diri seseorang dalam menempuh kehidupan.

\section{Maksud dan tujuan aktivitas komunikasi Tuan Guru Haji Hasanain Juaini, MH.}

Pelestarian lingkungan di zaman kejayaan Islam dahulu memang tidak begitu menuntut karena keadaan lingkungan pada saat itu tidak darurat ungkap Tuan Guru Haji Hasanain Juaini, MH. Namun dalil-dalil agama yang menganjurkan akan hal itu sudah dan tetap disampaikan, dan perintahnya dilaksanakan oleh mereka yang membutuhkan saja. Tidak seperti saat sekarang ini yang mana sangat darurat dan memerlukan gerakan masif untuk menyembuhkan kembali keadaan alam di sekitar kita. Untuk membuat semua orang melakukan pelestarian lingkungan, maka umat Islam sendiri yang harus menunjukkan secara langsung praktek-prakteknya (Wawancara dengan Tuan Guru Haji Hasanain Juaini, 20 Juni 2018).

Dari hasil obervasi penulis Tuan Guru Haji Hasanain Juaini, MH. selama hampir 20 tahun terakhir bergelut dengan pelestarian lingkungan. beliau bahkan memfokuskan segala kegiatannya agar memberikan manfaat pada pelestarian dan perbaikan lingkungan di sekitar beliau. Termasuk dalam kegiatan dakwah sebagai seorang Tuan Guru. Beliau ingin memberikan pemahaman dasar kepada masyarakat tentang pentingnya menjaga dan melestarikan lingkungan sebagai perintah agama melalui dalil-dalil yang telah tercantum di dalam Alquran dan 


\section{A. F. Aziz, Yaya, \& Bahrudin}

Hadis. Dengan memperhatikan segala aspek yang melekat pada masyarakat sasak Lombok, maka penyesuaian pesan, metode dan media untuk memahamkan mad'u tentang hal tersebut beliau lakukan dengan beberapa pendekatan.

Dalam perjalanan dakwahnya, Tuan Guru Haji Hasanain Juaini, MH. yang dianggap tuan guru kitab hijau karena mengeluarkan hukum fiqih bahwa setiap muslim wajib 'ain hukumnya menanam sebanyak 127 pohon selama hidupnya. Landasan logikanya sebagaimana adalah hasil riset yang telah dilakukan oleh Lembaga Ashoka Internasional bahwa setiap orang setidaknya menghabiskan 127 batang pohon untuk kebutuhan hidupnya. Sehingga beliau menyimpulkan, jika manusia ingin membalas budi kepada alam, maka ia harus menanam minimal 127 batang pohon. Mengutip wawancara beliau dengan Majalah Suara Hidayatullah (2012: 86), "Kita ingin memberikan landasan logika fiqihnya. Islam mengajarkan kebaikan harus dibalas dengan kebaikan, minimal setimpal. Lebih banyak lebih baik. Alam sudah memberi begitu banyak kepada manusia, karena itu manusia mesti membalas kebaikan alam tersebut", ungkap beliau.

Dalil hadis yang menurut Tuan Guru Haji Hasanain Juaini, MH. relevan dengan Hukum Lingkungan dan menjadi latar belakang yang mendorong beliau untuk melakukan penanaman pohon adalah hadis tentang sejarah perjalanan Salman Al-Farisi untuk masuk Islam. Dalam hadis itu diceritakan bahwa untuk menebus Salman Al-Farisi dari tuannya, dia harus membayar emas seberat 40 uqiyah dan menanam pohon kurma sebanyak 300 batang pohon (Wawancara dengan Tuan Guru Haji Hasanain Juaini, 20 Juni 2018).

Alquran menyatakan bahwa manusia diciptakan Allah Swt untuk beribadah dan melestarikan lingkungan sebagaimana tertera pada QS. Hud: 61 "Dia telah menciptakan kamu dari bumi (tanah) dan menjadikan kamu pemakmurnya" (Depag RI, 2015: 228). Menurut Tuan Guru Haji Hasanain Juaini, MH. kata ista'marakum dalam penggalan ayat di atas memanglah secara langsung memerintahkan manusia di bumi ini untuk memakmurkan lingkungannya walaupun tidak termasuk ke dalam rukun. Karena hal tersebut termasuk dari misi penciptaan manusia yang telah diberi anugrah oleh Allah Swt bentangan alam yang luas yang bisa mereka ambil manfaatnya, maka agar alam itu selalu dapat bermanfaat untuk manusia, sudah seharusnya mereka juga melestarikan lingkungannya (Wawancara dengan Tuan Guru Haji Hasanain Juaini, 20 Juni 2018).

Kondisi sosial masyarakat juga menjadi materi dakwah Tuan Guru Haji Hasanain Juaini, MH. Misalnya mengapa masyarakat tidak melestarikan lingkungannya atau mengapa masayarakat malah merusak lingkungannya. Perubahan global yang diakibatkan global warming terhadap lingkungan dan pola konsumsi masyarakat. Konsumsi manusia zaman dahulu yang terbatas oleh alat kini berubah karena banyak alat yang mendukung eksploitasi hasil bumi dengan jumlah banyak. Beliau sampaikan batasan-batasan yang harus dijaga 
dalam menggunakan alat tersebut demi menjaga kelestarian alam (Wawancara dengan Tuan Guru Haji Hasanain Juaini, 20 Juni 2018).

Dalam sebuah artikel yang diterima Tuan Guru Haji Hasanain Juaini, MH. yang ditulis oleh Dr. Nuzhmy Kholil, dinyatakan bahwa air hujan yang turun pada suatu wilayah Allah sesuaikan dengan banyak tanaman dan binatang yang ada di daerah itu. hal ini berdasarkan dalil QS. Al-Mu'minun: 18 "Dan Kami turunkan air dari langit menurut suatu ukuran” (Depag RI, 2015: 343). Landasan teologis yang juga mendukung adalah hadis Rasulullah Saw yang menerangkan bahwa binatang dan tanaman adalah makhluq Allah yang tidak memiliki akal fikiran sehingga tidak kuasa mencari di luar habitatnya dan tidak mampu juga mengakali untuk merekayasa pasokan air (Wawancara dengan Tuan Guru Haji Hasanain Juaini, 20 Juni 2018).

Bedasarkan hasil pengamatan penulis implementasi metode mau'iz̧ah basanah yang digunakan Tuan Guru Haji Hasanain Juaini, MH. untuk meyakinkan mad'u terhadap urgensi pelestarian lingkungan di antaranya membuat demo plot tempat program penghijauan dengan luas 36 hektar, membagikan satu juta bibit pohon secara gratis setiap tahun, dan membuat tungku pembakaran sampah untuk mengelolanya. Demo plot seluas 36 hektar tersebut di beri nama Desa Madani, berlokasi di Desa Sedau Kecamatan Narmada Kabupaten Lombok Barat. Karena keberhasilan beliau menghijaukan lahan yang sebelumnya sangat tandus itu beliau diberi penghargaan Ramon Magsaysay Award pada tahun 2011 di Manila Filipina.

Setelah melihat keberhasilan Tuan Guru Haji Hasanain Juaini, MH. masyarakat tidak serta merta mau untuk melakukan penanaman. Mengutip wawancara beliau dengan Majalah Suara Hidayatullah (2012: 86),

Sesungguhnya masyarakat ini protes. Yang ada di dalam pikiran mereka yang tinggal di pinggiran hutan adalah pemerintah lebih cinta kepada pohon ketimbang manusianya. Harkat kemanusiaan mereka protes, manusia boleh apa saja, yang penting pohonnya tetap hidup. Begitu pemahaman mereka. Nah, pemahaman seperti itu harus diubah.

Menyadari pemahaman masyarakat yang demikian, Tuan Guru Haji Hasanain Juaini, MH. perlu menyediakan solusi yang juga dapat dijadikan media untuk menyadarkan masyarakat tersebut. Beliau mulai dengan membagikan bibit secara gratis kepada siapa saja yang mau menanam. Beliau juga sering ikut langsung menanam bersama mereka yang meminta bibit-bibit tersebut. Setelah itu barulah masyarakat mulai percaya dan mau mengikuti langkah beliau (Suara Hidayatullah, 2012: 86).

Program pelestarian lingkungan tidak terlepas dari penertiban sampah, karena serimbun apapun alam ini akan tampak tidak lestari jika di sekitarnya sampah berserakan dan menumpuk. Air sungai yang mengalir deras pun dapat 


\section{A. F. Aziz, Yaya, \& Bahrudin}

menjadi bencana karena bercampur dengan sampah. Permasalahan sampah juga menjadi fokus Tuan Guru Haji Hasanain Juaini, MH. dalam pelestarian lingkungan. Beliau meyakini bahwa sampah yang tidak tuntas dikelola lebih berbahaya 24 kali dari pada sampah yang dibiarkan menginap. Artinya sampah yang ada pada hari ini harus tuntas dikelola hari ini juga, tidak hanya dibuang ke TPA lalu dibiarkan menumpuk. Dengan keyakinan tersebut beliau mencoba mengelola sampah yang ada di lingkungan pesantren dengan membuat tungku pembakar sampah senilai 30 juta rupiah. Tungku dengan teknologi plasma yang dipanaskan higga $1800^{\circ} \mathrm{C}$ mampu membakar setidaknya 2 ton sampah per harinya. Dengan teknologi plasma tersebut, partikel asap yang dikeluarkan juga menjadi lebih cepat terurai di udara. Dari pengolahan sampah ini, dapat pula mengahasilkan beberapa manfaat yang bisa menguntungkan (Wawancara dengan Tuan Guru Haji Hasanain Juaini, 20 Juni 2018).

Hasil pengamatan penulis mengenai media untuk mendakwahkan pelestarian lingkungan oleh Tuan Guru Haji Hasanain Juaini, MH yaitu ceramah, lahan untuk pembibitan seluas 1 hektar, dan tulisan. Mengisi kajian pada pengajian mingguan sebanyak 2 kali bertempat di Majlis Taklim Darul Hikmah yang dirintis ayah beliau. Selain itu menjadi penceramah pada acara-acara hari besar Islam maupun hari besar nasional. Menjadi narasumber pada sebuah acara diskusi ilmiah atau seminar tentang pelestarian lingkungan maupun pembangunan daerah berskala nasional maupun internasional.

Sebuah kawasan khusus tempat budidaya bibit di dalam lingkungan pesantren Tuan Guru Haji Hasanain Juaini, MH. yang dikelola dan dikerjakan oleh santri-santri beliau. Menurut beliau tempat itu tidak boleh kurang dari 1 hektar untuk menampung bibit yang banyak. Segala macam bibit disediakan dan masyarakat bisa mendapatkan bibit siap tanam secara geratis di tempat tersebut. Tempat inilah yang sering beliau beritakan melalui facebook atau surat kabar kepada masyarakat bahwa bibit yang siap diambil bagi siapa saja yang membutuhkannya (Wawancara dengan Tuan Guru Haji Hasanain Juaini, 20 Juni 2018).

Dari hasil pengamatan penulis Tulisan-tulisan Tuan Guru Haji Hasanain Juaini, MH. mengenai pelestarian maupun yang berkenaan dengan masalahmasalah sosial dan lain-lain dapat ditemukan di internet. Disamping itu juga melalui akun jejaring sosial facebook, beliau menulis dakwah atau ide-die dan gagasan beliau tentang pelestarian lingkungan maupun pembangunan daerah. Beliau juga berkirim surat kepada kepala-kepala dinas atau instansi pemerintahan di NTB, misalnya kepada Dinas Pendidikan dan Kementrian Agama. Melalui surat itu beliau menghimbau agar mereka menggerakkan para siswa sekolah dan madrasah yang ada di NTB untuk melakukan pelestarian lingkungan.

Dengan maksud mengajak mad'u untuk ikut menjaga dan melestarikan lingkungan disekitar mereka, Tuan Guru haji Hasanain Juaini, MH. 
menyesuaikan materi, metode dan media yang digunakan dalam berdakwah. Hal tersebut sesuai dengan faktor pembentuk pola komunikasi yang di paparkan Bambang Saiful Ma'arif (2010: 79) bahwa maksud dan tujuan dari aktivitas komunikasi sehingga membawa kepada penyesuaian pesan, metode, dan media yang dipergunakan.

\section{PENUTUP}

Pola dakwah Tuan Guru Haji Hasanain Juaini, MH. dalam rangka melestarikan lingkungan adalah sebuah bentuk perwujudan dari perintah Allah Swt kepada manusia untuk beribadah kepada-Nya dan melestarikan lingkungan disekitar mereka. Karena menurut beliau beribadah kepada Allah dan menjaga alam tidak dapat dipisahkan dari misi pencipataan manusia di atas bumi.

Dari sekian pembahasan yang telah penulis paparkan dapat ditarik kesimpulan sebagai berikut: pertama, faktor pembentuk pola dakwah Tuan Guru Hasanain Juaini, MH. dalam rangka melestarikan lingkungan adalah proses sejarah yang memeberikan pengalaman kepada beliau untuk melakukan pelestarian lingkungan serta mendakwahkannya kepada masyarakat dan mempengaruhi kebiasaan-kebiasaan dan menjadi kepribadian beliau. Beliau adalah pribadi da'i yang menyampaikan sesuatu berdasarkan apa yang beliau yakini dan telah beliau lakukan. Mendakwahkan sesuatu dengan cara yang baik dan disesuaikan dengan bahasa atau latar belakang mad'unya. Beliau siap menerima saran dan kritikan, menganjurkan untuk melakukan sesuatu secara langsung mengerjakannya sebagai contoh yang didorong oleh watak kritis masyarakat sasak Lombok. Kedua, Kapasitas pendidikan dan pengalaman Tuan Guru Haji Hasanain Juaini, MH. untuk melakukan pelestarian lingkungan serta mendakwahkannya kepada masyarakat, sesuai dengan faktor pembentuk pola komunikasi. Riwayat pendidikan dan pengalaman mendukung beliau untuk melakukan dakwah dan mengeluarkan hukum fiqih lingkungan yang menjadi dasar tujuan dakwah, materi dan metode beliau dalam menyampaikan dakwah pelestarian lingkungan. Ketiga, maksud dan tujuan aktivitas komunikasi Tuan Guru Haji Hasanain Juaini, MH. juga menjadi faktor pembentuk pola dakwah pelestarian lingkungan. Dengan maksud mengajak mad'u untuk ikut menjaga dan melestarikan lingkungan disekitar mereka, beliau menyesuaikan materi, metode dan media yang digunakan dalam berdakwah. Materi dakwah yang disampaikan Tuan Guru Haji Hasanain Juaini, MH. adalah materi fiqih lingkungan dan dalildalil agama yang mendasarinya. Metode beliau dalam mendakwahkannya adalah dengan kerja nyata melakukan penanaman, manyediakan bibit-bibit pohon siap tanam dan membagikannya secara gratis, kemudian mengelola sampah untuk menjaga kebersihan lingkungan. Media yang digunakan adalah ceramah, membuat areal khusus untuk budidaya bibit dan melalui tulisan. 
Setalah melakukan penelitian, penulis mengamati dan menyaksikan langsung pekerjaan-pekerjaan yang dilakukan Tuan Guru Haji Hasanain Juaini, MH. untuk kepentingan pelestarian lingkungan. semangat beliau dalam menjalankannya patut menjadi teladan bagi seluruh masyarakat yang juga peduli pada lingkungan di sekitar mereka. Oleh karena itu penulis sangat mengharapkan beliau bisa menghasilkan karya literasi yang menceritakan pengalaman beliau dalam melaksanakan dakwah pelestarian lingkungan ini. Dengan tujuan akan selalu muncul di masa yang akan datang da'i-da'i pejuang lingkungan yang terinspirasi dengan kerja keras beliau sehingga keberlangsungan pelestarian lingkungan tetap terus berlanjut. Penulis juga menyadari bahwa di dalam penelitian ini masih terdapat hal-hal yang perlu dilengkapi sehingga bagi siapa pun yang berminat melakukan penelitian mengenai Pola Dakwah Tuan Guru agar dapat meneruskan dan menutupi segala kekurangan yang ada di dalam penelitian ini.

\section{DAFTAR PUSTAKA}

Amin, S. M. (2009). Ilmu Dakwah. Jakarta: Amzah.

Aziz, A. F. (2018). Pola Dakwah Tuan Guru; Studi Deskriptif Pola Dakwah Tuan Guru Haji Hasanain Juaini, MH. Dalam Rangka Melestarikan Lingkungan di Pondok Pesantren Nurul Haramain NW Kecamatan Narmada Kabupaten Lombok Barat. Skripsi, Komunikasi dan Penyiaran Islam, Fakultas Dakwah dan Komunikasi, UIN Sunan Gunung Djati, Bandung.

Aziz, M. A. (2009). Ilmu Dakwah. Jakarta: Kencana.

Darmawan, I., \& Ramzi, M. (2013). Risalah Perjuangan Guru Wen. Yogyakarta: ArRuzz Media.

Depag RI. (2015). Al-Qur'an Tajwid \& Terjemah. Bandung: CV Penerbit Diponegoro.

Effendi, M. (2013). Tuan Guru dalam Masyarakat Sasak, diakses 3 Februari 2018, dari http:/ /akumassa.org/id/tuan-guru-dalam-masyarakat-sasak/

Ervina, M. (2015). Pola Komunikasi Tuan Guru dalam Melestarikan Lingkungan Hidup; Studi terhadap Kiprah TGH. Hasanain Djuaini, Lc. MH. Skripsi, Komunikasi dan Penyiaran Islam, Fakultas Dakwah dan Komunikasi, IAIN Mataram, Mataram.

Hananto, A. (2014). Tuan Guru Hasanain Juaini, Bung Karno dari Timur, diakses 3 Februari 2018, dari http://www.mongabay.co.id/2014/10/28/tuan-guruhasanain-juaini-bung-karno-dari-timur/

Ilahi, W. (2010). Komunikasi Dakwah. Bandung: PT Remaja Rosdakarya.

Juaini, H. (2015). Lorong Kerikil Tuan Guru. Mataram: LEPPIM IAIN Mataram.

Ma'arif, B. S. (2010). Komunikasi Dakwah, Paradigma Untuk Aksi. Bandung: Simbiosa Rekatama Media.

Nurjaman, A. (2016). Pola Komunikasi Kyai dalam Memelihara Solidaritas 
Jamaah dalam Ilmu Dakwah: Academic Journal for Homiletic Studies, 10(2), 305330.

Permana Y. H. (2016). Pola Tabligh Organisasi Jamiyah Nurul Iman Bandung dalam Tabligh: Jurnal Komunikasi dan Penyiaran Islam, 1(2), 37-59.

Subagyo, B. (2012). Figur Hasanain Juaini dalam Suara Hidayatullah, Februari, 8587.

Sujarweni, V. W. (2014). Metodologi Penelitian. Yogyakarta: Pustaka Baru.

Tahir, M. (2008). Tuan Guru dan Dinamika Hukum Islam di Pulau Lombok dalam Jurnal Asy-Syir'ah, 42(1), 94-115. 